Conflicts of interest The authors declare that they have no conflicts of interest in relation to this article.

Commissioned article; not externally peer-reviewed; accepted 1st February 2012; online 23rd February 2012

(c) 2012 Primary Care Respiratory Society UK. All rights reserved http://dx.doi.org/10.4104/pcrj.2012.00024

Prim Care Respir J 2012:21(2):124-6

\section{References}

1. Barbara AM, Loeb M, Dolovich L, Brazil K, Russell M. Agreement between selfreport and medical records on signs and symptoms of respiratory illness. Prim Care Respir J 2012;21(2):145-52. http://dx.doi.org/10.4104/pcrj.2011.00098

2. Barry CA, Bradley $C P$, Britten N, Stevenson FA, Barber N. Patients' unvoiced agendas in general practice consultations: qualitative study. BMJ 2000;320(7244): 1246-50. http://dx.doi.org/10.1136/bmj.320.7244.1246

3. Hamm RM, Hicks RJ, Bemben DA. Antibiotics and respiratory infections: are patients more satisfied when expectations are met? J Fam Pract 1996;43(1):56-62.

4. Cosby JL, Francis N, Butler CC. The role of evidence in the decline of antibiotic use for common respiratory infections in primary care. The Lancet (Infectious Diseases) 2007;7(11):749-56. http://dx.doi.org/10.1016/\$1473-3099(07)70263-3

5. Marra F, Patrick DM, Chong M, Bowie WR. Antibiotic use among children in British Columbia, Canada. Journal of Antimicrobial Chemotherapy 2006;58(4):830-9. http://dx.doi.org/10.1093/jac/dkl275

6. Cockburn J, Pit S. Prescribing behaviour in clinical practice: patients' expectations and doctors' perceptions of patients' expectations-a questionnaire study. BMJ 1997;315(7107):520-3. http://dx.doi.org/10.1136/bmj.315.7107.520

7. Himmel W, Lippert-Urbanke E, Kochen MM. Are patients more satisfied when they receive a prescription? The effect of patient expectations in general practice. Scand J Prim Health Care 1997;15(3):118-22.

http://dx.doi.org/10.3109/ 02813439709018500

8. de Lusignan S, Wells SE, Hague NJ, Thiru K. Managers see the problems associated with coding clinical data as a technical issue whilst clinicians also see cultural barriers. Methods Inf Med 2003;42(4):416-22.

9. Elstein AS, Schwarz A. Clinical problem solving and diagnostic decision making: selective review of the cognitive literature. BMJ 2002;324(7339):729-32. http://dx.doi.org/10.1136/bmj.324.7339.729

10. Gigerenzer G, Gaissmaier W. Heuristic Decision Making. Annual Review of Psychology 2011;62(1):451-82. http://dx.doi.org/10.1146/annurev-psych-120709145346.

11. Kahneman D, Tversky A. Subjective probability: a judgment of representativeness. Cognitive Psychology 1972;3:430-54. http://dx.doi.org/10.1016/0010-0285(72)90016-3

12. Gigerenzer G, Todd PM, and the ABC Research Group. (1999). Simple Heuristics That Make Us Smart. Oxford: Oxford University Press.

13. Gigerenzer G. Goldstein DG. Reasoning the fast and frugal way: models of bounded rationality. Psychological Review 1996;103:650-69. http://dx.doi.org/10.1037/0033-295X.103.4.650

14. Gilovich T, Griffin D. Kahneman D. (eds.). (2002). Heuristics and Biases: The Psychology of Intuitive Judgment. Cambridge, UK.: Cambridge University Press.

15. Fitter MJ and Cruickshank PJ. The computer in the consulting room: a psychological framework. Behaviour and Information Technology 1983;1:81-92. http://dx.doi.org/10.1080/01449298208914438

16. Alsanjari ON, de Lusignan S, van Vlymen J, et al. Trends and transient change in end-digit preference in blood pressure recording: studies of sequential and longitudinal collected primary care data. Int J Clin Pract 2012;66(1):37-43. http://dx.doi.org/10.1111/j.1742-1241.2011.02781.x

17. Rosser WW. Threat of litigation. How does it affect family practice? Can Fam Physician 1994;40:645-8.

18. Summerton N. Positive and negative factors in defensive medicine: a questionnaire study of general practitioners. BMJ 1995;310(6971):27-9. http://dx.doi.org/10.1136/bmj.310.6971.27

19. Teichman PG. Documentation tips for reducing malpractice risk. Fam Pract Manag 2000;7(3):29-33

20. Bishop TF, Federman AD, Keyhani S. Physicians' views on defensive medicine: a national survey. Arch Intern Med 2010;170(12):1081-3. http://dx.doi.org/10.1001/archinternmed.2010.155

21. Weed LL. Medical records that guide and teach. N Eng/ J Med 1968;278(11):593600. http://dx.doi.org/10.1056/NEJM196803142781105

\title{
Streptococcus pyogenes upper respiratory infections and their effect on atopic conditions
}

\section{See linked article by Juhn et al. on pg 153}

\section{*Osman Mohammad Yusufa}

a The Allergy and Asthma Institute, Islamabad, Pakistan

*Correspondence: Dr Osman M Yusuf, The Allergy and Asthma Institute, 275 Gomal Road, Sector E-7, Islamabad, Pakistan 44000 Tel: (0092) 512654445 Fax: (0092) 512654446

E-mail: osman_allergy@yahoo.com

The effect of the upper airway on the lower airway was recognised as early as the second century by Claudius Galenus, who defined the nose as a 'respiratory instrument' in his work De usu partium (On the usefulness of the [body] parts). ${ }^{1}$ However, the modern concept of the upper and lower respiratory passages being a continuum and forming a single unified airway has been highlighted only over the last 10-15 years. ${ }^{2}$

The Allergic Rhinitis and its Impact on Asthma (ARIA) initiative focused on the co-morbidities of allergic rhinitis and included involvement of the eyes, the paranasal sinuses and the lower airways. ${ }^{3}$ The nasal and bronchial mucosa present a number of similarities, and one of the most important concepts regarding nose/lung interactions is their functional complementarity. ${ }^{4}$ Interactions between the upper and lower airways are well known; it has been observed that over $80 \%$ of asthma patients have rhinitis and $10-40 \%$ of patients with rhinitis have asthma. ${ }^{3}$

The role of upper respiratory tract infections (URTIS) and how they affect the lower respiratory tract have been less well studied compared to the role of allergic diseases. Similarly, the effects of URTIs on atopic conditions (other than asthma) have also not been documented to any appreciable extent. Asthma in children is associated with an increased risk of Streptococcus pyogenes upper respiratory infections, ${ }^{5}$ even though Strep. pyogenes is not known to be a cause of asthma exacerbations. ${ }^{6}$

Strep. pyogenes is a well-known causative agent of a number of autoimmune conditions. The relatively new disease PANDAS, supposedly of post-streptococcal etiology, is the acronym for Paediatric Autoimmune Neuropsychiatric Disease Associated with Streptococcal 
infection. Tics and obsessive-compulsive symptoms are the major clinical signs of the disease, which develops after Streptococcus infection and which is almost certainly caused by autoimmune mechanisms (though the exact nature of the autoimmune mechanism remains unclear). Some cases of chronic urticaria are also reported to be associated with chronic tonsillitis, ${ }^{8}$ although the primary role of infection in chronic urticaria is controversial.

Mast cells play a key role in the pathogenesis of atopic diseases as well as in asthma. They are important effector cells in innate immune responses to bacterial infections, and are critically involved in initiating and modulating optimal host responses to bacteria by either inflammatory or anti-inflammatory effects depending on the course of the host reaction induced by the pathogen. The exact mechanism for this is not known. ${ }^{9}$ However, one possible mechanism is via the Th-1 pathway through the induction of interleukin-12 (IL-12); a topical preparation OK-432, prepared from the penicillin-treated Su strain of type III Group A Strep. pyogenes, has been shown to be effective for treating atopic dermatitis. ${ }^{10}$

Children sensitised to house dust mite (HDM) have early defective antibody responses to bacteria that are associated with asthma, and the presence of antibacterial IgE has been associated with a reduced risk for asthma. ${ }^{11}$ This suggests that a functioning humoral immune system prevents the development of asthma, and possibly the development of other atopic diseases as well. The immune system's response to infections and its effects on allergy have been studied by Essilfie and co-workers in BALB/c mice. ${ }^{12}$ These workers found that the combination of infection and allergic airways disease promotes bacterial persistence, leading to the development of a phenotype similar to steroid-resistant neutrophilic asthma - and hence the suggestion that steroid-resistant asthma may result from dysfunction in innate immune cells. Targeting bacterial infection in steroid-resistant asthma may therefore have therapeutic benefit.

In this issue of the PCRJ, Juhn and colleagues have retrospectively studied the association of Strep. pyogenes and atopic conditions other than asthma in children under the age of 18 years $^{12}$ - an area of research which has been poorly studied in the past. They selected 143 $(44 \%)$ of their total sample size who met the criteria of having atopic conditions other than asthma. They collected the laboratory test results of cultures, rapid antigen detection, and polymerase chain reaction tests for Strep. pyogenes infections during the first 18 years of life, and compared the incidence of Strep. pyogenes infections between children with and without a physician diagnosis of an atopic condition. They used a Poisson regression to determine the association between asthma and Strep. pyogenes infections, controlling for other covariates including asthma. They found that the incidence of Strep. pyogenes infections in children with atopic conditions other than asthma, and those without atopic conditions, was 0.24 per personyear and 0.18 per person-year, respectively. They conclude that, in addition to asthma, allergic rhinitis but not atopic dermatitis is associated with an increased risk of Strep. pyogenes URTIs.

The authors have looked at many potential hypotheses to explain this linkage, but none with any amount of convincing evidence. ${ }^{12}$ In addition, and as stated by the authors themselves, there are several limitations to this study, not least the fact that it is retrospective and observational, so only an associational relationship could be documented. Furthermore, relevant risk factors like exposure to indoor cigarette smoking or allergic sensitisation status data were not available, and the study population was predominantly Caucasian.

Nevertheless, the overall results of this study suggest that there may be a link between the immunogenetic predisposition to atopy and susceptibility to Strep. pyogenes infection, thus opening up a new area for research. Primary care practitioners are advised to keep this in mind when they see patients with repeated URTIs. In addition, repeated URTIs in children with symptoms of tics - such as repeated eye blinking or clearing of the throat - may be an early sign of chronic Strep. pyogenes infection and PANDAS. One must also not forget to examine for additional allergy-associated conditions including (but not limited to) asthma.

Acknowledgements The author gratefully acknowledges the assistance of Dr Arzu Mammadova, Allergist, Central Hospital of Oil Workers, Department of Chest Diseases, Baku, Azerbaijan, who kindly provided information on PANDAS.

Conflicts of interest The author is an Associate Editor of the PCRJ, but was not involved in the editorial review of, nor the decision to publish, this article.

Commissioned article; not externally peer-reviewed; accepted 3rd April 2012; online 17th May 2012

(c) 2012 Primary Care Respiratory Society UK. All rights reserved http://dx.doi.org/10.4104/pcri.2012.00034

Prim Care Respir J 2012;21(2):126-7

\section{References}

1. Lenfant C. Introduction. In: Corren J, Togias A, Bousquet J, eds. Upper and Lower Respiratory Disease Lung Biology in Health and Disease C Lenfant editor Vol 181. NY: Marcel Dekker 2004:iii-iv.

2. Jay Grossman. One Airway, One Disease. Chest 1997;111:11S-16S http://dx.doi.org/10.1378/chest. 111.2_Supplement.11S.

3. Bousquet J, Van Cauwenberge $P$, Khaltaev N. Allergic rhinitis and its impact on asthma. J Allergy Clin Immunol 2001;108(5)(Suppl):S147-334 http://dx.doi.org/10.1067/mai.2001.118891

4. Togias A. Rhinitis and asthma: evidence for respiratory system integration. J Allergy Clin Immunol 2003;111(6):1171-83; quiz 84.

http://dx.doi.org/10.1067/ mai.2003.1592

5. Frey D, Jacobson R, Poland G, Li X, Juhn Y. Assessment of the association between pediatric asthma and Streptococcus pyogenes upper respiratory infection. Allergy Asthma Proc 2009;30(5):540-5. http://dx.doi.org/10.2500/aap.2009.30.3268

6. Weinberger M. Respiratory infections and asthma: current treatment strategies. Drug Discov Today 2004;9(19):831-7. http://dx.doi.org/10.1016/\$1359-6446(04)03239-8

7. de Oliveira SK. PANDAS: a new disease? J Pediatr (Rio J) 2007;83(3):201-08 http://dx.doi.org/10.2223/JPED.1615

8. Calado G, Loureiro G, Machado D, et al. Streptococcal tonsillitis as a cause of urticaria Tonsillitis and urticaria. Allergol Immunopathol (Madr) 2011 Oct 5. [Epub ahead of print].

9. Metz M, Magerl M, Kühl NF, Valeva A, Bhakdi S, Maurer M. Mast cells determine the magnitude of bacterial toxin-induced skin inflammation. Exp Dermatol 2009;18(2):160-6. Epub 2008 Jul 17 http://dx.doi.org/10.1111/j.1600-0625.2008.00778.x

10. Horiuchi Y. Topical streptococcal preparation, OK-432, for atopic dermatitis. J Dermatolog Treat 2005;16(2):117-20. http://dx.doi.org/10.1080/09546630510032709

11. Hales BJ, Chai LY, Elliot CE, et al. Antibacterial antibody responses associated with the development of asthma in house dust mite-sensitised and non-sensitised children Thorax 2011 Nov 21. [Epub ahead of print]

12. Juhn YJ, Frey D, Lic X, Jacobson R. Streptococcus pyogenes upper respiratory infection and atopic conditions other than asthma: a retrospective cohort study. Prim Care Respir J 2012;21(2):153-8. http://dx.doi.org/10.4104/pcrj.2011.00110 